УДК 821.161.2-311.3.09Галетка

Ковпік Світлана, доктор філологічних наук, професор, професор кафедри української та світової літератур Криворізький державний педагогічний університет

\title{
ФУНКЦІЯ ГРОШЕЙ В АВАНТЮРНОМУ РОМАНІ ОЛЕГА ГАЛЕТКИ «ГРОШІ, КУБА І ЛІТЕРАТУРА»
}

У статті йдеться про функиію грошей у житті письменника. Авторка статті спробувала визначити вплив, залежність, прив'язаність до грошей людини мистецтва слова. А також розглянула наслідки процесу написання творів художньої літератури за гроші для психіки письменника. Окрім изього, у статті визначено рівень економічної свідомості персонажів творів. Розглянуто роль грошей у житті персонажів різних сочіальних прошарків. Помічено, що ставлення персонажів до грошей виконує щуе й характеристичну функиію. Деякі персонажі роману «Гроші, Куба $і$ література» обирають гроші як інструмент формування способу життя. За гроші купують любов, свободу, витвір мистецтва, рідних. Лексема «гроші», котра у назві є релевантною перебуває у сильній позииії в тексті роману. 3'ясовано, що міра вартості праці письменника визначається 
сумою, котру донька олігарха витрачає за тиждень. Гроші виконують у романі свою економічну функиію - міра вартості.

Ключові слова: гроші, письменник, мистецтвво, література, економічна свідомість, міра вартості, спосіб життя.

\section{Galetka.}

Kovpik S. Money function in the adventure novel "Money, Cuba and Literature" by Oleg

The article investigates the function of money in the writer's life. This paper represents the attempt to determine the money influence, its dependence and attachment to the person of the word art. It also describes the consequences of writing fiction works for money on the writer's state of mind. In addition, the article defines the level of economic consciousness of the characters. Moreover it studies the role of money in the life of characters from different social strata. It is noted that the attitude of the characters to money also performs their characterizing function. Some characters in the novel "Money, Cuba and Literature" choose money as a tool for lifestyles. They buy love, freedom, works of art, and relatives for money. The word "money", which is relevant in the title, takes a strong position in the text of the novel. It is shown that the value of the writer's labor is determined by the amount of money spent by the tycoon's daughter in a week. Money performs its economic function of value standard in the novel.

Key words: money, writer, art, literature, economic consciousness, value standard, lifestyle.

Письменник і гроші - це та тема в українській літературі, котру можна віднести до вічних тем. Як відомо, в українській літературі письменники літературною працею заробляли собі на життя (І. Франко), а деякі через брак грошей не мали можливості надрукувати свої твори або ж не мали ані копійки на життя, а тому змушені були свої твори продавати будь-кому аби тільки вижити (В. Стефаник). Гроші та ставлення до них персонажів творів перебували у центрі уваги таких письменників: I. Карпенка-Карого «Сто тисяч», I. Франка «Гава» та ін.

Тема письменник і гроші не менш актуальна й сьогодні в сучасній українській літературі. Про це свідчить авантюрний роман Л. Галетки «Гроші, Куба і література» (2013). Останнім часом цей роман отримав чимало рецензій та відгуків, у яких, переважно, акценти ставилися на стилістиці художнього тексту, жанрових особливостях твору, творчій манері автора. Проте гроші та їхні функції у вказаному творі не були спеціальним предметом вивчення у жодній із наукових розвідок.

Тож у нашій статті спробуємо проаналізувати функції та сутність грошей в авантюрному романі О. Галетки «Гроші, Куба і література». 
Як відомо, у класичній економічній теорії виокремлюють п’ять основних функцій грошей: міра вартості, засіб обігу, засіб творення скарбів, засіб платежу, світові гроші. Функція грошей як міри вартості полягає у здатності грошей вимірювати вартість усіх товарів, надаючи їй форму ціни. Гроші як міра вартості широко використовуються як одиниця рахування. За їх допомогою можна надати кількісного виразу всім економічним процесам i явищам. Функція засобу платежу полягає в обслуговуванні грошима погашення різноманітних боргових зобов'язань між суб'єктами економічних відносин. Цю функцію гроші здійснюють як у сфері товарного обігу (продаж товару в кредит, погашення боргу), так і поза ним при погашенні різних зобов’язань (заробітна плата, сплата податків, орендна і квартирна плата, повернення позик тощо). Функцію утворення скарбу виконують ті гроші, які виходять з обігу, нагромаджуються і перетворюються на скарб у своїй золотій або срібній формі. Що ж до функції світових грошей, то вона пов’язана 3 обслуговуванням грошима міжнародних економічних відносин, зовнішньоторговельних операцій. Окрім суто економічних функцій гроші виконують низку інших, а саме: інструмент формування способу життя, інструмент мотивації трудової діяльності, засіб організації підприємництва тощо [3].

В економічній літературі перелік функцій грошей за останні роки помітно розширився. 3'явилися такі функції, як: комунікативна, миротворча. Усе це вказує на значну еволюцію сутності грошей в суспільстві та розширення масштабів їх використання. У статті акцент будемо робити переважно не на економічних функціях грошей, а на суспільній.

Лексема «гроші»є релевантною вже в самій назві роману, котра свідчить про те, що саме гроші у творі займають досить сильну позицію. У значно слабшій позиції в структурі назви роману «Гроші, Куба i література» знаходиться лексема «література». Отже, письменник самою назвою акцентує увагу реципієнта на тому, що гроші у його творі будуть відігравати важливу роль. 
Так, за гроші із кишені купують витвір молодого письменника, який спочатку із сумом та обуренням приймає жорстоку реальність, але згодом усвідомлює: «Нехай не його ім'я буде на книжиі, але цุе однаково крок до успіху, якщуо з'явилися люди, які бажають платити за його слова. За його тридияять тисяч слів і декілька розумних думок. I він щзе про щзось думає ? Він намагається знайти виправдання собі ? Він... він щзе раз подивився на гроші. Дві тисячі доларів. Три або чотири місячні зарплатні. Скільки він писав ияі тридиять слів ? Два місяџі. Дебет сходився із кредитом. Числа окупали себе, але от тільки внутрішне «я» не визнавало циифр» [2, с. 17]. У цих роздумах привертає увагу те, що людина мистецтва послуговується стандартизованими методологічними прийомами бухгалтерського обігу «дебіт i кредит» для позначення власного прибутку. Що свідчить про достатньо задовільний рівень економічної свідомості персонажа.

Більше того, молодий письменник прораховує обсяг заробітку за рукопис відповідно до рівня його заробітної плати за місяць. Усе це свідчить про те, що гроші в його житті є засобом виживання, а тому він змушений продавати свої рукописи. С. Галетка торкнувся дуже вразливої теми - теми молодого митця та його шлях визнання у сучасному суспільстві. Адже для презентації своїх літературних творів молодому письменнику потрібні не тільки оцінки рецензентів, солідний тираж його творів, а й гроші, котрі він витратить на публікацію свого твору в солідному видавництві. Ось тому головний персонаж роману молодий письменник Микола йде на компроміс зі своєю совістю. Через що він терзається, мучиться, але необхідність і потреба в грошах беруть верх.

Узявши гроші за свій рукопис, молодий письменник Микола ще довго розмірковував над своїм вчинком, але потім себе заспокоїв тим, що він просто людина, яка набирає тексти. Тож гроші, які він отримав - це ціна за набраний текст. Автор звертає увагу на те, як саме після підписання угоди про продаж рукопису Микола забрав гроші: «...niдхопив стосик купюр» [2, с. 19]. Саме «підхопив», бо він відчував деяку огиду до свого вчинку, адже він митець продав найдорожче, що в нього було - художній твір. 
Після того, як Микола забрав гроші за свій роман його охопили роздуми. Спочатку він думав, що продешевив, потім він заглибився у всю сутність продажу свого твору і прийшов до висновку, що він зрадив себе. Сумніви, каяття не давали йому спокою. Молодий письменник неодмінно хотів дізнатися те, хто ж тепер є автором його роману, якою буде реакція читача на його твір. Ось тому він щодня ходив до книжкової крамниці і цікавився як його роман купують, що про нього кажуть читачі. І це зрозуміло, бо для людини мистецтва iii витвір дорогий як для матері дитина.

Сила грошей $\mathrm{y}$ романі відчувається $\mathrm{y}$ характеристиках майже всіх персонажів твору. Так, головний редактор видавничого будинку «Продакшбук» Суриков Веніамін Павлович використовує гроші для відкупів за свої аморальні вчинки, олігарх Ігор Вікторович Соломахін за гроші купує любов єдиної розбещеної доньки Віолети, наречений Віолети Вадим накопичує гроші, щоб виїхати на острів свободи Куба і там жити так, як йому заманеться. Начальнику охорони Соломахіна Дмитрові гроші потрібні для сестри Мері, яка ніде не працює, а лише паразитує за рахунок брата. Вона розважається, їздить відпочивати за п’ять тисяч доларів на місяць за кордон. Сестра ніколи не питає де брат бере гроші, адже ії це абсолютно не цікавить.

Отже, гроші у творі літератури виконують характеристичні функції персонажів. Грішми вимірюються стосунки, комфорт, свобода, масштаб розваг і відпочинку, а найстрашніше любов рідних. Майже усім персонажам роману потрібні гроші, усі вони пройняті думкою про те, де і як їх роздобути.

Письменник акцентує увагу на тому, що міра вартості праці письменника Миколи дорівнює сумі, котру донька олігарха Віолета витрачає за тиждень. А письменнику початківцю цих грошей вистачить майже на півроку життя. У даному епізоді гроші виконують суто економічну функцію - міра вартості.

У хлопця Віолети Вадима, який мріє виїхати на Кубу є своя теорія грошей, котра розкриває одну із їх функцій - інструмент формування способу життя: «Ми будемо вільні від грошей, тому щь громі будуть пращювати на нас, але вони потрібні. Я не фанатик, який вірить, буцุімто гроші - ие зло. Гроші - 
ųе знаряддя, иче спосіб досягнення Свободи» [2, с. 76-77]. Ось тому і Віолету Вадим розглядав як головного інвестора для реалізації своєї мрії, а там де мова йшла про гроші, то ні про які почуття не можна було мріяти. Від дівчини йому були потрібні лише гроші. Відповідно, коли Віолеті залишила його, він вирішив пограбувати іï багато батька. Для поїздки до омріяної країни Свободи йому потрібно було лише десять тисяч доларів. Міра вартості його свободи - це десять тисяч американських доларів заради яких він готовий піти на кримінал.

У романі С. Галетки «Гроші, Куба і література» можна дуже добре проаналізувати ставлення до грошей персонажів на різних вікових етапах. Так, для молоді гроші потрібні, щоб бути незалежними і вільними на омріяному острові Свободи. Заради цієї ідеї вони готові на порушення норм закону. Ось як письменник описує стан Вадима, коли той зламав сейф Соломахіна 3 грошима: «Сейф клачнув і відкрився. Вадим спочатку не повірив. Посмішка заграла на його обличчі. Усередині акуратними стосиками лежали гроші. Багато грошей. Мінімум півмільйона в доларах США» [2, с. 166]. Вадим, якому для поїздки на острів Свободи потрібно було лише десять тисяч американських доларів, не зупинився на потрібній сумі, а взяв усе, що лежало у сейфі. Тож сама маса грошей і доступність до них підживили зажерливість хлопця. Цей вчинок ще раз підтвердив народну мудрість про те, що «всьому є межа, але людській жадібності іï немає».

Головному редактору Сурикову, вже зовсім немолодому чоловіку, гроші потрібні, щоб задовольнити свої огидні фізіологічні потреби. І він теж заради цього готовий піти всупереч нормам закону. За чужий рахунок він готовий задовольнити свої фізіологічні потреби, але коли мова зайшла про те, що він повинен викласти власні гроші, то цей чоловік одразу відмовився від своєї огидної ідеї.

Для олігарха Соломахіна, котрий усе життя накопичував та примножував свій капітал чесними й не зовсім чесними шляхами, гроші основна складова його життя, а точніше сенс його життя. Тобто, гроші перетворилися 3 простого 
механізму досягнення цілі в саму ціль, підмінюючи собою увесь процес мотивації.

У романі вибудовується досить оригінальна схема міжлюдських стосунків, де гроші (особливо чужі) виконують функцію контролювання, врегулювання. Серед персонажів роману «Гроші, Куба і література» заробляють гроші тільки письменник Микола та олігарх Соломахін. Шляхи та способи заробітку ними грошей суттєво різняться. Проте, на відмінну від решти персонажів, вони вміють і знають як заробити гроші. А ось решта персонажів твору демонструють звичайний паразитизм. I дочка Соломахіна, i Вадим, i Суриков, і спільнота вільних людей за рахунок чужої праці і грошей мріють реалізувати свої життєві плани. У даному випадку тут дуже добре спрацьовує теорія грошей Г. Зіммеля, котрий стверджував, що гроші несуть суттєві зміни у внутрішній світ людей, їхніх інтересів, прагнень і навіть моральних критеріїв. Гроші у романі «Гроші, Куба і література» принципово змінюють систему людських цінностей.

I оскільки ставлення до грошей персонажів - це багаторівнева цілісна система, то на певному етапі життя під впливом різних компонентів (пізнавального, емоційного, мотиваційного) відбувається домінування одного iз них.

На прикладі олігарха Соломахіна, автор показує те, як гроші формують особливий стиль мислення - калькуляція усіх процесів не тільки свого життя, а життя близьких та рідних. Олігарх грошима вимірює усі стосунки, гроші це інструмент його влади у світі загального безгрошів’я. Пропонуючи донці вечерю разом з іï матір'ю, Соломахін не забув підкреслити, що вони можуть поїсти за його рахунок. Таке акцентування на своїй платоспроможності ще раз підтверджуєте, що гроші для Соломахіна - це засіб самоутвердження та влади. Він добре відчуває, що від його грошей залежать члени родини, а тому намагається їм диктувати свій принцип життя. Олігарх керуються тим, що в сучасному світі гроші найбільший та універсальний сигнал лідерства людини, його переваги над іншими. 
Отже, в аналізованому романі С. Галетки «Гроші, Куба і література» гроші виконують низку функцій, а саме: характеротворчу, контролю, економічну (міра вартості), засіб досягнення мети. Усі персонажі так чи так пов'язані з грошима. Цілі й наміри щодо їх накопичення усіх різні. Так, для письменника Миколи - це всього на всього засіб існування, для Віолети і Мері засіб розваг, для Вадима - це можливість отримати свободу і жити так, як його заманеться. Проте хлопець не враховує те, що він не зовсім й вільна людина, адже залежність його від грошей очевидна. Грошима вимірюються стосунки між батьками і дітьми, між коханими, між друзями. Таким чином, гроші стали також головним персонажем аналізованого роману.

Тож вважаємо, що надалі тема економічного дискурсу та функцій грошей у сучасній українській літературі є досить перспективною, адже художній твір літератури сьогодні $є$ поліфункціональним явищем, котре презентує цікаві схеми функціонування грошей і капіталу, способи його накопичення.

\section{Література}

1. Зиммель Г. Философия денег / Г. Зиммель // Теория общества : Фундаментальные проблемы. - Москва : КАНОН-пресс-Ц ; Кучково поле, 1999. - C. 33-89.

2. Галетка О. Гроші, Куба і література : роман [Текст] / О. Галетка. Харків : Клуб сімейного дозвілля, 2013. - 284 с.

3. Челноков В. Эволюция денег : монография / В. Челноков. - Москва : Финансы и статистика, 2008. - 456 с. 